\title{
Modeling The Effects Of Social Integration And Job Autonomy On Job Satisfaction Among School Sport Facilitators In Southern Gauteng
}

M. Dhurup, Vaal University of Technology, South Africa

\begin{abstract}
Research within the domain of job satisfaction has brought about renewed interest among human resource practitioners and researchers in the past twenty years. Furthermore, many studies have examined the antecedents of job satisfaction in various organisational settings. However, focusing on social integration and job autonomy relationships with work outcomes have been limited and worthy of empirical investigation. The purpose of the study was to examine the relationship between social integration and job autonomy on job satisfaction among school sport facilitators. The study is located with a quantitative research paradigm. A structured questionnaire consisting of validated scales for social integration, job autonomy and job satisfaction was administered to a sample of 201 school sport facilitators in the Southern Gauteng region of South Africa. The results show significant positive correlations among the constructs, social integration, and job autonomy and job satisfaction. In addition, social integration, a facet of $Q W L$ life and job autonomy was found to significantly influence job satisfaction. Confirmatory factor analysis (CFA) was used to examine the fit to the proposed model and the path model using structural equation modelling (SEM) to examine casual relationships among the constructs. Results show satisfactory goodnessof fit indices. The path model showed strong casual relationships indicating that social integration and job autonomy of school sport facilitators significantly related to job satisfaction. The results demonstrate that the higher the prevalence of social integration and job autonomy, the higher the levels of job satisfaction. It is recommended that sport facilitators should be given adequate autonomy to make decisions about the services they render and any top-down imposition of change may be counter-productive to job satisfaction among sport facilitators.
\end{abstract}

Keywords: Social Integration; Job Autonomy; Job Satisfaction; Sport Facilitators; Secondary Schools

\section{INTRODUCTION}

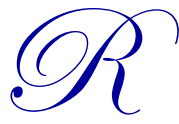

esearch within the domain of job satisfaction has brought about renewed interest among human resource practitioners and researchers in the past twenty years and whenever job satisfaction and related constructs are researched new points emerge harmonising the relationship aspects of quality of life (QWL) and various human resource outcomes (Llorente \& Macias, 2005). The driving force behind the increased interest in personal well-being of employees is the need to find out whether employees are satisfied with their jobs (Nguyen, Taylor and Bradley, 2003). Earlier, Freeman (1978:135) pointed out, "the answers to questions about how people feel toward their job are not meaningless but rather convey useful information about economic life that should not be ignored". Quality of work-life (QWL) is a multi-faceted construct encompassing various aspects of work life. QWL is a comprehensive construct that encompasses an individual's job related well-being and the extent to which work experiences are rewarding, fulfilling and devoid of stress and other negative personal consequences (Reddy \& Reddy, 2010). Walton (1974) proposed the conceptual categories of QWL and suggested eight dimensions that encapsulate employee's perceptions towards their work, namely: adequate and fair compensation, a safe and healthy environment, development of human capacities, growth and security, social 
integration, total life space, constitutionalism and social relevance. Walton's (1974) eight-part typology of the dimensions of QWL remains a useful analytical tool in measuring the construct (Normala, 2010). One of the factors which impacts on school sport facilitators QWL is their ability to engender social integration in the work place. The study inter-alia examines one of the many aspects of QWL, namely social integration and its relationship with job satisfaction.

Research on job autonomy on the other hand has gained the attention of researchers because of the benefits it brings not only to employees but also to organisations (Naqvi, Ishtiaq, Kanwal \& Ali, 2013). Autonomy is actually one of the job design characteristics (Smith, Kot \& Leat, 2003). Job autonomy improves performance because when employees are able to exercise a certain level of job autonomy; they consider that they are trusted to perform the task well.

\section{Social Integration}

Social integration has been described in literature to understand both social structure and individual behaviour. On the individual level, social integration is defined as structural or affective interconnectedness with others and with social institutions (Berkman \& Glass, 2000). The structural component of social integration incorporates a behavioural component in which individuals participate in formal organisations and informal social relationships such as working within the community or neighbourhood. Affectiveness interconnectedness may be positive or negative, whereby the relationship may be supportive or demanding. Hence, the work demands of sport facilitators encompass a range of demands that are associated with the job.

Relationships between and among the employees is an indicator of healthy work organisations. Hence, employees must be provided an environment whereby formal and informal interactions can take place. Employees often develop their personal identity and self-esteem through their workplace climate such as freedom from prejudice, sense of community, interpersonal openness and the possibility of upward mobility (Walton, 1974). Employees must be given the perspective of how his/her work in the organisation helps the society. This is essential to build relevance of the employee's existence to the society in which he/she lives in (Reddy \& Reddy, 2010). Hence it is proposed that high levels of social integration in the work place of sport facilitators may enhance their level of job satisfaction.

\section{Job Autonomy}

A factor that is believed to influence job satisfaction is job autonomy (Nguyen, et al., 2003). Job autonomy is defined as the degree to which the job offers considerable liberty, providing a free hand to the individual in scheduling the work also defining the means to achieve their tasks (Morgeson, Delaney-Klinger \& Hemingway, 2005). Stamps and Piedmonte (1986) define autonomy as the amount of job-related independence, initiative, and freedom permitted or required in daily work activities. Autonomy involves exercising control over methods used to perform work activities, the scheduling of those activities, and the standards used to judge performance (Breaugh, 1985).

More autonomy is expected to be associated with greater job satisfaction because workers have more freedom to determine their own effort and work schedule especially if working in sport facilitation/coaching environment. Very few studies have examined the impact of job autonomy on job satisfaction (Nguyen et al., 2003). Studies have investigated the influence of job autonomy on job satisfaction which was primarily qualitative in nature (Landeweed \& Bouman, 1994; Schienman, 2002) which were descriptive and employing a small sample. Autonomy seems to be emerging as a key variable when examining educational reform initiatives, with some arguing that granting autonomy especially within sporting contexts empowers educators to perform better and assist in solving the problems in schools (Melenyser, 1990; Short, 1994). If educators who take on the additional role of sport facilitators are to be empowered and exalted as professionals, then like other professions, educators must also have the freedom and autonomy in their workplace (Pearson \& Moomaw, 2005). Job autonomy enhances employees' feelings that job outcomes are a result of their efforts (Wang \& Netemeyer, 2002). Both qualitative and quantitative research in the field of organisational behaviour suggests positive relationships between job autonomy and job 
satisfaction (Nguyen, etal., 2003). Hence, it is proposed that high levels of work autonomy may lead to high levels of job satisfaction among sport facilitators.

\section{Job Satisfaction}

Job satisfaction has become a highly important area of research in social sciences. There are various compelling reasons why an employer should care about job satisfaction. Job satisfaction is generally defined as a positive emotional state that reflects an affective response to a job situation (Locke, 1976). Job satisfaction is one of the central variables in work and is seen as an important indicator of working life quality (Aryee, Fields \& Luk, 1999). Satisfaction and contentment of an individual in work and off work aspects are essential in maintaining overall life balance (Sadri \& Goveas, 2013). The relationship between quality of life aspects and job satisfaction has in the past been investigated by researchers (Chitra \& Mahalakshmi, 2012). Different methods have been used in the past, both to measure global and facet specific job satisfaction. In addition, different scales have been developed and different aspects of the job have been taken into account.

Job satisfaction has been chosen for the study because it is one of the most widely studied variables in organisational research (Cranny, Smith \& Stone, 1992). In addition, it has shown to have meaningful relationships to a number of important variables such as performance, organisational citizenship behaviour and turnover intentions. Furthermore, there has been a limited amount of research addressing the relationship between autonomy and various outcomes variables, including job satisfaction (Denton \& Kleiman, 2001).

From a humanistic view, it is assumed that satisfaction with job is a basic value that should be attainable for all sport facilitators, and that the provision of avenues for social integration and job autonomy at the workplace may result in workers to be satisfied with their jobs. For the study, job satisfaction is used as a dependable variable and social integration and job autonomy was used as independent variables.

\section{RESEARCH HYPOTHESES}

In the light of the research and rational arguments presented, the following hypotheses were formulated:

H1: Sport facilitators' social integration at work is positively and significantly related to job satisfaction.

H2: Sport facilitators' job autonomy is positively and significantly related to job satisfaction.

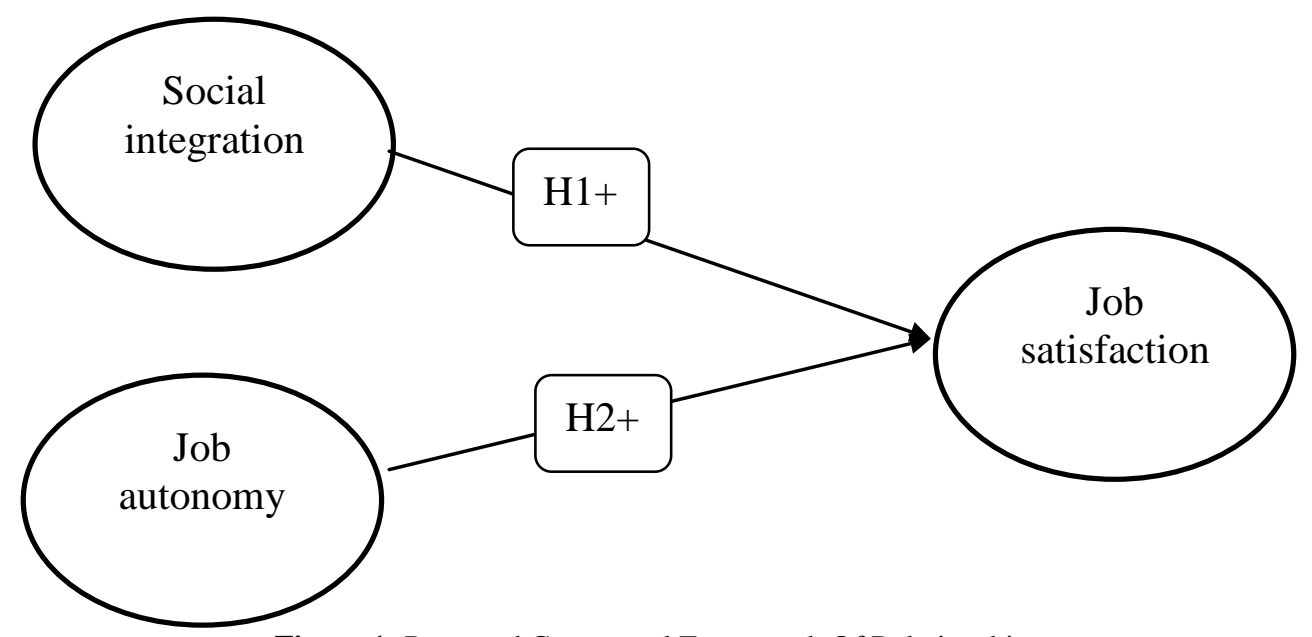

Figure 1: Proposed Conceptual Framework Of Relationships 


\section{RESEARCH METHODOLOGY}

The study utilised a quantitative research design using a structured questionnaire. The design was suitable to solicit the required information relating to social integration, job satisfaction and job autonomy. In addition, the approach enables to examine the causal relationships with the constructs used in the study.

\section{Target Population}

The target population of the study were restricted to sport facilitators who were employed in various public primary schools in Southern Gauteng, in South Africa. This area was chosen because negligible empirical studies has been carried out for this group in order to understand the relationship with regard to social integration, job satisfaction and job autonomy among this cohort.

\section{The Sample}

The sample comprised schools sport facilitators who were educators that were employed permanently in public schools in Southern Gauteng. Apart from teaching, these educators also contributed to coaching sport codes based on their current /previous knowledge of sport participation either as a participant and knowledge of their chosen sport. These participants were considered competent to evaluate their social integration within the community and subsequent evaluation of their own job satisfaction and work autonomy. Eight school educators distributed the questionnaires in public schools for a three month period (September 2013-November 2013). A total of 217 questionnaires were collected from respondents. A covering letter accompanied the questionnaire stipulating the purpose of the study. In addition, the covering letter ensured respondents anonymity and confidentiality regarding the name of the school and the participant. A total of 201 questionnaires were eventually used for the analysis as 16 were discarded due to incomplete responses on the questionnaire.

\section{Research Instrumentation}

The questionnaire was developed through a literature review on previous research studies. Adaptations were made to the questionnaire to suit school sport facilitators. The social integration scale was adapted from the Walton's (1974) typology of the quality of work life dimensions. Job satisfaction was measured on a 5-item scale originally used by Brayfield and Rothe (1951). In empirical research, autonomy has traditionally been operationalised through variables that measure the employees' opportunities to be independent concerning the workers ability and opportunity to determine what tasks to do, how to do the work, and what the aim of the work should be. Sport facilitators were asked to respond to each item based on a 5-point Likert scale ranging from 1= strongly agree to $5=$ strongly disagree.

\section{Data Collection}

Participation in the survey was voluntary. The questionnaire was administered by a Department of Education staff member who worked in the various districts in Southern Gauteng region who in turn made use of key staff members in the various districts to administer and collect the questionnaires. The primary field worker and key staff members were remunerated for their fieldwork duties.

\section{INSTRUMENT RELIABILITY AND VALIDITY}

In accordance with the two-step procedure suggested by Anderson and Gerbing (1988), prior to testing the hypotheses, confirmatory factor analysis (CFA) was performed to examine reliability, convergent and discriminant validity of the multi-item construct measures using AMOS 21.0. Overall acceptable model fit are indicated by Goodness-of-Fit Index (GFI) $\geq 0.80$; Adjusted Goodness-of Fit Index (AGFI) $\geq 0.80$; Root Mean Square Error of Approximation (RMSEA) values $\leq 0.08$; Incremental Index of Fit (IFI),Tucker-Lewis Index (TLI) and ComparativeFit Index (CFI) values $\geq 0.90$; and Chi-square degrees of freedom ratio (CMIN/DF) value $<3$. Recommended statistics for the final overall model assessment show acceptable fit of the measurement model to the data: chi-square value over degrees $=227.983(100), \mathrm{CMIN} / \mathrm{DF}=2.280 ; \mathrm{GFI}=0.901 ; \mathrm{AGFI}=0.830 ; \mathrm{IFI}=0.982$; 
$\mathrm{TLI}=0.972 ; \mathrm{CFI}=0.9982 ; \mathrm{RMSEA}=0.066$. Loadings of individual items on their respective constructs are shown in Table 2, while the scale construct correlations are presented in Table 1. The individual item loadings are all above there commended level of 0.50 (Anderson \& Gerbing, 1988), indicating acceptable individual item reliabilities as more than 50 per cent of each item's variance is shared with its respective construct. Composite reliabilities (CR) and average variance extracted (AVE) for each construct were also computed using the formula proposed by Fornell and Larcker (1981). The results are shown in Table 1, and descriptive statistics and correlations among the study constructs are presented in Table 2. The composite reliabilities (CR) are all above the recommended value of 0.7 suggested by Hulland (1999) thus indicating acceptable internal consistency and reliability of the respective measures. All average variance extracted (AVE) values were above 0.50 thus accepted according to the literature as this results provided evidence for acceptable levels of research scale reliability (Fraering \& Minor, 2006). Discriminant validity was established by checking if the AVE value was greater than the highest shared variance (SV) value of 0.50 (Fornell \& Larcker 1981). The results presented in Table 1 indicate that the minimum AVE value is 0.83 for each construct which is greater than the highest shared variance (0.77). Secondly, the study checked if the correlations between the constructs were below a unit value of 1.000. The maximum correlation value between the constructs were 0.910 thus providing evidence of discriminate validity. Overall, the study provided adequate evidence that the measurement scales used in the study were reliable and valid.

Table 1: Means, Reliability And Accuracy Analysis Statistics

\begin{tabular}{|c|c|c|c|c|c|c|c|}
\hline \multirow[b]{2}{*}{$\begin{array}{l}\text { Constructs And Brief } \\
\text { Descriptions }\end{array}$} & \multirow[b]{2}{*}{ Means } & \multicolumn{2}{|c|}{ Cronbach's Tests } & \multirow[b]{2}{*}{$\begin{array}{l}\text { C.R. } \\
\text { Value }\end{array}$} & \multirow[b]{2}{*}{$\begin{array}{l}\text { AVE } \\
\text { Value }\end{array}$} & \multirow[b]{2}{*}{$\begin{array}{c}\text { Shared } \\
\text { Variance }\end{array}$} & \multirow[b]{2}{*}{$\begin{array}{c}\text { Factor } \\
\text { Loadings }\end{array}$} \\
\hline & & $\begin{array}{c}\text { Item-Total } \\
\text { Correlations } \\
\end{array}$ & $\begin{array}{c}\alpha \\
\text { Values } \\
\end{array}$ & & & & \\
\hline Construct 1: Social integration & 2.50 & - & 0.98 & 0.97 & 0.85 & $\mathbf{0 . 7 7}$ & - \\
\hline Discrimination in your work place & 2.51 & 0.908 & & & & & 0.910 \\
\hline $\begin{array}{l}\text { Relationship with your colleagues } \\
\text { and bosses }\end{array}$ & 2.52 & 0.939 & & & & & 0.955 \\
\hline $\begin{array}{l}\text { Team's and colleagues' } \\
\text { commitment to work }\end{array}$ & 2.49 & 0.943 & & & & & 0.953 \\
\hline $\begin{array}{l}\text { Confidence of your ideas and } \\
\text { initiatives }\end{array}$ & 2.46 & 0.936 & & & & & 0.947 \\
\hline $\begin{array}{l}\text { Sense of belonging in the } \\
\text { community }\end{array}$ & 2.52 & 0.924 & & & & & 0.939 \\
\hline $\begin{array}{l}\text { Organisation's contribution to } \\
\text { social responsibility }\end{array}$ & 2.52 & 0.916 & & & & & 0.918 \\
\hline $\begin{array}{l}\text { Organisation's commitment to } \\
\text { ethical behaviour }\end{array}$ & 2.47 & 0.932 & & & & & 0.923 \\
\hline $\begin{array}{l}\text { Organisation's commitment to } \\
\text { serve as an agent for social change }\end{array}$ & 2.48 & 0.871 & & & & & 0.894 \\
\hline Construct 2: Job satisfaction & 2.60 & - & 0.98 & 0.97 & $\mathbf{0 . 8 8}$ & 0.82 & - \\
\hline Real enjoyment as a coach & 2.64 & 0.937 & & & & & 0.958 \\
\hline $\begin{array}{l}\text { Like my job better than the average } \\
\text { person }\end{array}$ & 2.60 & 0.938 & & & & & 0.970 \\
\hline Seldom get bored with my job & 2.61 & 0.921 & & & & & 0.925 \\
\hline $\begin{array}{l}\text { Would not consider taking another } \\
\text { job }\end{array}$ & 2.58 & 0.956 & & & & & 0.941 \\
\hline Enthusiastic about my job & 2.58 & 0.967 & & & & & 0.945 \\
\hline Satisfied with my job & 2.58 & 0.932 & & & & & 0.916 \\
\hline Construct 3: Job autonomy & 2.61 & - & 0.97 & 0.95 & $\mathbf{0 . 8 3}$ & 0.82 & - \\
\hline Freedom to do what you want & 3.93 & .697 & & & & & 0.932 \\
\hline Left alone to do your job & 3.71 & .656 & & & & & 0.961 \\
\hline Act independently & 3.47 & .686 & & & & & 0.954 \\
\hline Job allows independent thought & 3.58 & .700 & & & & & 0.944 \\
\hline
\end{tabular}

Strong positive and significant correlations were noted between social integration $(r=0.803 ; p<0.01)$ and job satisfaction and job autonomy $(r=0.910 ; \mathrm{p}<0.01)$ and job satisfaction. 
Table 2: Descriptive Statistics And Correlations Between Constructs

\begin{tabular}{lccccc}
\hline \multicolumn{1}{c}{ Constructs } & \multicolumn{3}{c}{ Descriptive statistics } \\
\cline { 2 - 6 } & Mean & SD & SI & JS & JA \\
\hline Social integration (SI) & 2.50 & 0.766 & 1.000 & $0.882^{*}$ & $0.803^{*}$ \\
\hline Job satisfaction (JS) & 2.60 & 0.835 & $0.882^{*}$ & 1.000 & $0.910^{*}$ \\
\hline Job autonomy (JA) & 2.61 & 0.873 & $0.803^{*}$ & $0.910^{*}$ & 1.000 \\
\hline$*$ Correlations are significant at the 0.01 level (2-tailed) & & & &
\end{tabular}

* Correlations are significant at the 0.01 level (2-tailed).

\section{STRUCTURAL MODEL ASSESSMENT}

In order to test the direct effects of social integration of sport facilitators and job autonomy on job satisfaction, structural modelling (SEM) was performed. Figure 2 provides the results of the path modelling.

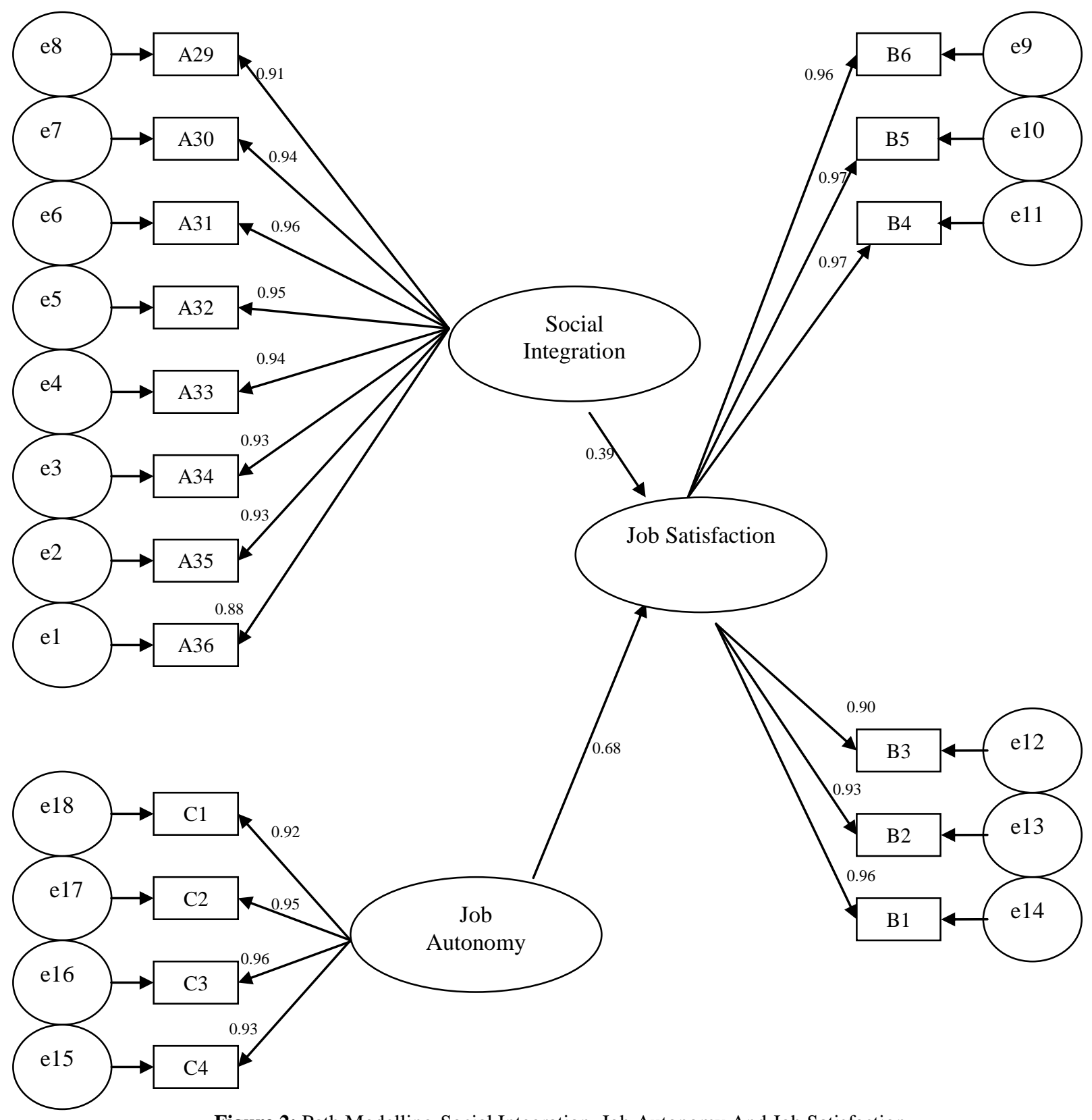

Figure 2: Path Modelling-Social Integration, Job Autonomy And Job Satisfaction 
The maximum likelihood estimation (MLE) method was used because it has desirable asymptotic properties (e.g. minimum variance and unbiasedness). The model is acceptable in terms of overall goodness of fit. The results indicate that, the CMIN/DF $=2.294$, CFI (0.982), IFI (0.982), TLI (0.974), RMSEA (0.078) and therefore achieved the acceptable level as suggested by Browne and Cudeck (1993) and Marsh, Balla and Hau (1996). This suggests that the model converged to exhibit convergent validity and could be a plausible representation of underlying empirical data structures collected in within a South African context.

The results of the hypotheses testing together with the significance levels and decision criteria on whether to support or reject the hypotheses are summarised in Table 3.

Table 3: Results Of The Structural Equation Model Analysis

\begin{tabular}{lcccc}
\hline \multicolumn{1}{c}{ Proposed hypotheses } & Hypothesis & Path Coefficients & p-value & Rejected/Supported \\
\hline Social integration $\rightarrow$ Job satisfaction & H1 & $0.392^{*}$ & $0.000^{*}$ & Supported \\
\hline Job autonomy $\rightarrow$ Job satisfaction & H2 & $0.667^{*}$ & $0.000^{*}$ & Supported \\
\hline$*$ significant at $\mathrm{p}<0.01$ & & & &
\end{tabular}

\section{DISCUSSION OF RESULTS}

\section{Sample Composition}

In terms of gender there was a fairly even distribution of males $(n=101 ; 50.2 \%)$ and females $(n=100$; $49.8 \%)$. Majority of the respondents' ages ranged from $31-40$ years $(n=68 ; 33.8 \%)$ followed by the age group, 20 30 years $(n=62 ; 30.8 \%)$ years, the age group, $41-50$ years $(n=38 ; 18.9 \%)$ and the age group over 50 years $(n=33$; $16.4 \%)$. Common codes of sport coached were as follows: soccer $(n=70 ; 34.8 \%)$, hockey $(n=58 ; 28.9 \%)$, netball $(\mathrm{n}=46 ; 22.9 \%)$. Rugby, a popular sport among Whites did not feature as a frequent sport played as the sport facilitators were predominately black staff in the township schools. Majority $(n=154 ; 76.6 \%)$ of the respondents reported to be earning between R15 000 to R20 000 per month. In terms of respondents frequency of coaching, majority $(\mathrm{n}=182 ; 90.5 \%)$ coached in schools once per week.

\section{Social Integration-Job Satisfaction Relationships}

The first hypotheses sought to establish the relationship between social integration with job satisfaction among school sport facilitators. A positive and significant association was posited in this relationship. Table 3 shows a positive and significant relationship (H1) with regard to this relationship (path coefficient $=0.392$ ) at $\mathrm{p}<0.000$. This relationship indicates that the greater the prevalence of social integration at the workplace, the higher the levels of job satisfaction among sport facilitators. This could be attributed perhaps to the notion than when sport facilitators take this addition role, they consider imparting their knowledge, skills and experience that they have learnt in the past as part of their contribution to the learner community (school learners) in which they are part of. Furthermore, sports facilitators may often seek solace that they acceptable to the community and its people in order to develop a strong bond in order to fit to the community (Chinomona, Dhurup \& Chinonoma, 2013). These findings are consistent with previous research who reported that work-life variables to direct affect job satisfaction (Olsen \& Near, 1994; Chitra \& Mahalakshmi, 2012)

\section{Job Autonomy-Job Satisfaction Relationships}

The second hypothesis posited a positive and significant relationship with sport facilitator's job satisfaction. The results (Table 3) show a strong positive and significant relationship (H2) between the constructs (path coefficients $=0.067$ ) at $\mathrm{p}<0.000$. This relationship indicates that the greater the prevalence of job autonomy at the workplace, the higher the levels of job satisfaction among sport facilitators. Nguyen et al. (2003) found that the degree of job satisfaction is highly and statistically related to job satisfaction. As job autonomy increases from "no freedom' to "limited freedom", for example, the workers satisfaction also increased. Sport facilitators can be successful if they are granted autonomy to make decisions in their work. Chung (1977) emphasised that autonomy has an impact on work methods, work pace and goal setting. Thus individuals with autonomy have the liberty to control the pace of work and to regulate work processes and evaluation procedures which may result in using skilful 
and creative initiatives in accomplishing their tasks and performing the job better (Saragih, 2011). Previous researchers also found positive association between job autonomy and job satisfaction (Finn, 2001; Thompson \& Prottas, 2005).

Furthermore, according to the work-role transitions theory (Nicholson, 1984) autonomous workers are able to determine the means and ends of their work. A study undertaken by Fulford and Enz (1995) revealed that autonomy accounted for approximately $15 \%$ of the variance in job satisfaction clearly indicating that there is a positive relationship between the variables. Earlier studies of Spector (1986) also found significant relationships between autonomy and a variety of outcomes variables including job satisfaction.

Interesting to note that job autonomy reflects stronger levels of job satisfaction compared to the social integration-job satisfaction relationships. Perhaps this could be explained by the fact that sport facilitators are given more freedom and an expression of their interest in sport facilitation which in turn engenders satisfaction with the job. Chelladurai and Kuga (1996) argued that coaching among secondary school teachers compared to teaching allows for greater influence by the leader/facilitator because of: smaller group sizes, member homogeneity and ability levels and higher intensity of motivation to participate in sport. In addition, sport facilitators may enjoy better leader-member relations (for example, respect); operates in a better defined task situation and holds greater power and exerts more control over operations because of some level of job autonomy (freedom). These attributes make it easier for a coach /facilitator to influence learners within a school context.

\section{LIMITATIONS}

There are several limitations of this study which provide opportunities for future research on social integration, job autonomy and job satisfaction. First, the sample was limited to public schools in one country and in Southern Gauteng only. Private schools were not part of the study. Future studies could also draw comparisons on these variables with job satisfaction with private schools as sport facilitators/coaches in these schools are often hired and paid for their expertise compared to those that are currently employed in public schools who assume such functions as part of their delegated duties apart from teaching. Generalisations from this study must be treated with caution. Public schools districts across the country vary in culture, school leaderships and expectations. Such variations may significantly influence the perceptions of social integration, job autonomy and job satisfaction. A more complete analysis over a larger sample size may be required for those teachers who also facilitate sport activities. However, the study was founded upon a fairly substantive body of previous empirical findings, which attest to the findings that the causal relationships are correctly specified. Despite these limitations, the research findings support the descriptive literature on the possible relationships among the constructs used in the study, namely social integration, job autonomy and job satisfaction. Further research should include a qualitative investigation into cultural differences and its effects on these and other constructs such as job performance, absenteeism and turnover intentions. Replication of this study is therefore warranted because this research has been exploratory in nature; future development of the robustness of the scale is required as this study is a valuable first step towards a better understanding of these antecedents and its relationship with job satisfaction among sport facilitators.

\section{CONCLUSION}

Job satisfaction is a topic of considerable interest to employee and employers. It is important for workers to be happy in their work, given the amount of time they have to devote in their workplace. Sport facilitators must have the authority to make decisions about the services they render and any top-down imposition of change is counter to the development of professionalism (Firestone \& Bader, 1992). The findings demonstrate that the greater the propensity for social integration and job autonomy the greater the propensity for school sport facilitators to be satisfied with the job.

\section{AUTHOR INFORMATION}

Prof Manilall Roy Dhurup is currently the Executive Dean in the Faculty of Management Sciences at the Vaal University of Technology, in South Africa. His research interest is in Marketing and Sport Marketing, Consumer 
Behaviour, Organisational behaviour and General management. His has more than 90 publications to his credit in national and international peer reviewed journal. He has travelled widely and presented numerous papers and national and international conferences. He current offers the research methodology and statistical induction program for post-graduate students at the University. E-mail: royd@ @ut.ac.za

\section{REFERENCES}

1. Anderson, J. C., \& Gerbing, D. W. (1988). Structural equation modeling in practice: A review and recommended two-step approach. Psychological Bulletin, 103, 411-423.

2. Aryee, S., Fields, D., Luk, V. (1999). A cross-cultural test of model of the work-family interface. Journal of Management, 25(4):491-511.

3. Berkman, L. F., \& Glass, T. (2000). Social integration, social networks, social support, and health. In L. F. Berkman \& I. Kawachi (Eds.), Social epidemiology (pp. 137-173). New York: Oxford University Press.

4. Brayfield, A., \& Rothe, H. (1951). An index of job satisfaction.Journal of Applied Psychology, 35,307-311.

5. Breaugh, J.A. (1985). The measurement of work autonomy. Human Relations, 38, 551-570.

6. Browne, M.W., \& Cudeck, R. (1993). Alternative ways of assessing model fit. In: K. A. Bollen, J. S. Long (Eds.). Testing Structural Equation Models, (pp.136-161), Newbury Park, CA: Sage,.

7. Chelladurai, P., \& Kuga, D.J. (1996). Teaching and coaching: group and task differences. Quest, 48, 470485 .

8. Chinomona, R., Dhurup, M., \& Chinomona, E. (2013). Does employee perceptions of fit to job, fit to organisation and fit to community influence job performance? The case of Zimbabwe's manufacturing sector. South African Journal of Human Resource Management, 11(1), Art.\#475http://dx.doi.org/10.4102/sajhrm.v11i1.475.

9. Chitra, D., \& Mahalakshmi, V. (2012). A study on employees' perception on quality of work life and job satisfaction in manufacturing organisations-an empirical study. International Journal of Trade and Commerce, 1(2): 175-184.

10. Chung, K. (1977). Motivational Theories and Practices. Columbus, OH: Grid Publishing.

11. Cranny. C. J., Smith, P .C., \& Stone, E. F. (1992). Job satisfaction: How people feel about their jobs and how it affects their performance. New York: Lexington Books

12. Denton, D.W., \& Kleiman, L.S. (2001). Job tenure as a moderator of the relationship between autonomy and satisfaction. Applied Human Resource Management Research, 6(2):105-114.

13. Finn, C.P. (2001). Autonomy: an important component for nurses' job satisfaction. International Journal of Nursing Studies, 38, 349-357.

14. Firestone, W.A., Bader, B.D. 1992. Redesigning teaching: Professionalism or bureaucracy? Albany: NY: State University of New York Press.

15. Fornell, C. \& Larcker, D. (1981). 'Structural equation models with unobservable variables and measurement error'. Journal of Marketing Research, 18 (1): 39-50.

16. Fraering, M., \& Minor, M. S. (2006). 'Sense of community: An exploratory study of US consumers of financial services'. International Journal of Bank Marketing, 24 (5): 284-306.

17. Freeman, R. B. (1978). Job satisfaction as an economic variable. American Economic Review, 86(2):135141.

18. Fulford, M.D., \& Enz, C.A. (1995). The impact on empowerment on service employees. Journal of Managerial Issues, 7,161-175.

19. Hulland, J. (1999). Use of partial least squares (pls) in strategic management research: a review of four recent studies. Strategic Management Journal, 20(2):195-204.

20. Landeweed, J.A., Bouman, N.P.G. (1994). The effect of work dimensions and need for autonomy on nurses' work satisfaction and health. Journal of Occupational and Organisational Psychology, 67:207-217.

21. Llorente, R.M. B., \& Macias, E.F. (2005). Job satisfaction as an indicator of the quality of work. The Journal of Socio-Economics, 34, 656-673.

22. Locke, E.A. (1976). The nature and causes of job satisfaction. In Dinette, N.D. (Ed). Handbook of Industrial and Organisational Behaviour. Rand-McNally, Chicago. (pp.1297-1349)

23. Marsh, H.W., Balla, J.R., \& Hau, K.T. (1996). An evaluation of incremental fit indices: a clarification of mathematical and empirical properties. In G.A. Marcoulides and R.E. 
24. Schumacker (Eds.) Advanced structural equation modeling, issues and techniques. N.J. Lawrence Erlbaum Associates Publishers, Mahwah, pp. 315-353.

25. Melenyzer, B.J. (1990). Teacher empowerment: The discourse, meanings, and social actions of teachers. Paper presented at the annual Conference of the National Council of States on In-service Education, Orlando, FL.

26. Morgeson, F.P., Delaney-Klinger, K., \& Hemingway, M.A. (2005). The importance of job autonomy, cognitive ability, and job-related skill for predicting role breadth and job performance. Journal of Applied Psychology, 90:399-406.

27. Naqvi, S.M.M.R., Ishtiaq, M., Kanwal, N., \& Ali, M. (2013). Impact on job autonomy on organisational commitment and job satisfaction: the moderating role of organisational culture in the fast food sector of Pakistan. International Journal of Business and Management, 8(17):92-102.

28. Nguyen, A.N., Taylor, J., \& Bradley, S. (2003). Job autonomy and job satisfaction: new evidence. Available at; http://www.lums.co.uk/publicationsLUMS. Date accessed: 13 December 2013.

29. Nicholson, N. (1984). A theory of work role transitions. Administrative Science Quarterly, 29, $172-191$.

30. Normala, D. (2010). Investigating the relationship between quality of work life and organisational commitment amongst employees in Malaysian firms. International Journal of Business Management 5, 10:75-82.

31. Olsen, D., \& Near, J.P. (1994). Role conflict and faculty life satisfaction. Review of Higher Education, 17(2):179-195.

32. Pearson, L.C., \& Moomaw, W. (2005). The relationship between teacher autonomy and stress, work satisfaction, empowerment and professionalism. Educational Research Quarterly, 29(1): 38-54.

33. Reddy, A., Reddy, M.P. 2010. Quality of work life of employees: emerging dimensions. Asian Journal of Management Research, 827-839.

34. Sadri, S., \& Goveas, C. (2013). Sustainable quality of work life and job satisfaction (An Indian Case). Elite Research Journal of Education and Review, 1(5):48-54.

35. Saragih, S. (2011). The effects of job autonomy on work outcomes: self efficacy as an intervening variable. International Research Journal of Business Studies, 4(3): 203-215.

36. Schienman, S. (2002). Socio-economic status, job conditions, and well-being: self-concept explanations for gender-contingent effects. The Sociological Quarterly, 43, 627-646.

37. Short, P.M. (1994). Defining teacher empowerment? Education, 114(4):488-493.

38. Smith, E.S., Kot, G.E., \& Leat, M. 2003. Differentiating work autonomy facets in a non-western context. Journal of Organisational Behaviour, 24(6):709-731.

39. Spector, P.E. (1986). Perceived control by employees: a meta-analysis of studies concerning autonomy and participation at work. Human Relations, 39, 1005-1016.

40. $\quad$ Stamps, P.L. \& Piedmonte, E. B. (1986). Nurses and work satisfaction. Ann Arbor, MI: Health Administration Press.

41. Thompson, C.A., \& Prottas, D.J. (2005). Relationship among organisational family support, job autonomy, perceived control and employee well-being. Journal of Occupational Health Psychology, 10(4): 100-118.

42. Walton, R.E. (1974). QWL indicator: Prospect and problems. Harvard Business Review, 63, 77-84.

43. Wang, W., \& Netemeyer, R.G. (2002). The Effects of Job Autonomy, Customer Demandingness, and Trait Competitiveness on Salesperson Learning and Self-Efficacy, Journal of Academy of Marketing Science, 30 (3), 217-228. 